\title{
Seleksi Fitur dan Penanganan Imbalanced Data menggunakan RFECV dan ADASYN
}

\author{
Irfan Pratama $^{1}$, Albert Yakobus Chandra ${ }^{2}$, Putri Taqwa Prasetyaningrum ${ }^{3}$ \\ Program Studi Sistem Informasi \\ Universitas Mercu Buana Yogyakarta \\ Yogyakarta, Indonesia \\ e-mail: 1irfanp@mercubauana-yogya.ac.id, ${ }^{2}$ albert.ch@mercubauana-yogya.ac.id, ${ }^{3}$ putri@mercubauana- \\ yogya.ac.id
}

Diajukan: 21 Juni 2021; Direvisi: 28 September 2021; Diterima: 30 September 2021

\begin{abstract}
Abstrak
Proses data mining bekerja terhadap data yang tersedia. Jika dataset tidak tersedia sepenuhnya, hasil pengolahan data mining menjadi tidak optimal. Terdapat beberapa kondisi data yang perlu penanganan terlebih dahulu sebelum memasuki tahap data mining. Salah satunya ialah imbalanced class yang merupakan kondisi di mana distribusi data pada setiap kelas tidak proporsional. Sebagai salah satu cara untuk efisiensi proses klasifikasi, seleksi fitur dapat memenuhi kebutuhan tersebut karena hasil dari seleksi fitur adalah sebuah dataset dengan jumlah atribut yang lebih sedikit dari sebelumnya. Untuk menyelesaikan permasalahan imbalanced class, ADASYN digunakan dalam penelitian ini sebagai metode untuk menyeimbangkan proporsi kelas pada dataset. Sedangkan RFECV digunakan sebagai metode fitur seleksi yang dapat meningkatkan efisiensi pada proses klasifikasi. Setelah dilakukan evaluasi dari hasil klasifikasi pada dataset yang menggunakan seleksi fitur, didapatkan hasil klasifikasi yang lebih baik dibandingkan dengan hasil klasifikasi pada dataset tanpa seleksi fitur. Hal tersebut dibuktikan dengan perbandingan antara hasil terbaik dari akurasi klasifikasi dataset tanpa seleksi fitur. Hasil dari metode CART sebesar $85.1 \%$ yang merupakan hasil dari pengolahan data tanpa menggunakan metode fitur seleksi. sedangkan metode Bagging k-NN yang menghasilkan akurasi sebesar $88 \%$ yang di aplikasikan pada dataset dengan seleksi fitur. Sehingga dapat disimpulkan bahwa seleksi fitur dapat meningkatkan akurasi pada klasifikasi.
\end{abstract}

Kata kunci: Data mining, Seleksi fitur, Imbalanced class, Bagging k-NN, RFECV, ADASYN.

\begin{abstract}
The data mining process works on the available data. If the dataset is not fully available, the results of data mining processing will not be optimal. Several data conditions need to be handled first before entering the data mining stage. One of them is an imbalanced class, which is a condition where the distribution of data in each class is not proportional. As a way to improve the efficiency of the classification process, feature selection can meet these needs because the result of feature selection is a dataset with fewer attributes than before. To solve the imbalanced class problem, ADASYN is used in this study as a method to balance the class proportions in the dataset. While RFECV is used as a feature selection method that can increase efficiency in the classification process. After evaluating the classification results on the dataset using feature selection, the classification results are better than the classification results on the dataset without feature selection. This is proved by the comparison between the best results of dataset classification accuracy without feature selection. The result of the CART method is $85.1 \%$ which is the result of data processing without using the feature selection method. while the Bagging $k$-NN method which produces an accuracy of $88 \%$ is applied to the dataset with feature selection. So it can be concluded that feature selection can improve classification accuracy.
\end{abstract}

Keywords: Data mining, Imbalanced class, Feature selection, Bagging k-NN, RFECV, ADASYN.

\section{Pendahuluan}

Dalam perkembangan teknologi saat ini, di mana data menjadi sebuah komoditi yang berharga bagi sektor apa pun yang ada di dunia ini. Dengan menggunakan data, sebuah informasi dan pengetahuan dapat diperoleh. Data mining merupakan sebuah disiplin ilmu yang dapat mengubah kumpulan data-data 
yang terlihat tidak merepresentasikan apa pun menjadi sebuah pengetahuan yang dapat digunakan oleh pemangku kepentingan dalam mengambil keputusan atau mengetahui kondisi saat ini[1]. Data mining menjadi salah satu tahap dari serangkaian proses penggalian pengetahuan yang lebih umum disebut sebagai Knowledge Discovery in Database (KDD), dalam rangkaian pengolahan data tersebut terdapat beberapa tahapan yang dilalui. Tahapan-tahapan tersebut tergantung pada kebutuhan dari proses data mining yang akan dilakukan. Secara umum, tahapan dari rangkaian proses KDD adalah data acquisition, preprocessing, data mining, evaluation, interpretation. Pada rangkaian tersebut dimungkinkan terdapat proses-proses kecil yang dimaksudkan untuk menunjang proses data mining yang dilakukan. Sebagai contoh, jika dataset yang digunakan adalah data kategorial dan digunakan untuk proses klasifikasi mengalami ketidakseimbangan pada distribusi kelasnya. Dataset yang di dalamnya terdapat missing values, atau dataset yang memiliki begitu banyak atribut dan diinginkan untuk mencari tahu mana saja data yang penting untuk digunakan. Hal-hal tersebut memiliki mekanisme penyelesaiannya masing-masing secara spesifik. Untuk data yang distribusi kelasnya tidak seimbang dapat ditangani oleh metode-metode untuk imbalanced class. Untuk dataset yang memiliki missing values dengan jumlah yang banyak dapat menggunakan pendekatan imputation. Sedangkan untuk dataset yang memiliki atribut yang banyak dan menginginkan adanya efisiensi proses dan mencari atribut mana yang optimal dan penting dapat menggunakan seleksi fitur.

Pada kenyataannya, tidak semua dataset tersedia secara sempurna. Terlebih jika data tersebut adalah data asli yang secara aktual didapatkan dari proses observasi atau pengambilan data primer. Jika terdapat dua atau lebih kelompok yang memisahkan antar data-data tersebut atau yang biasa disebut klasifikasi, proporsi sebaran data antar masing-masing kelas menjadi penting untuk diperhatikan. Proses data mining yang bekerja terhadap data yang tersedia akan mengolah data seperti apa adanya. Jika ketersediaan data tidak dipastikan terlebih dahulu, maka hasil dari proses data mining menjadi tidak optimal. Kondisi data dengan sebaran tiap kelas yang tidak proporsional disebut dengan imbalanced class. Kondisi tersebut dapat menyebabkan bias pada hasil klasifikasi yang dilakukan karena jumlah data yang dapat digunakan untuk pembelajaran model menjadi tidak seimbang antara satu kelas dengan kelas lainnya. Terdapat beberapa mekanisme yang dapat menangani masalah tersebut yang terbagi menjadi dua pendekatan yaitu pendekatan level data, dan pendekatan level algoritme[2]. Metode-metode yang secara umum digunakan untuk menangani kondisi seperti itu adalah metode dari pendekatan level data. seperti yang dilakukan oleh [3] yang menggunakan SMOTE sebagai metode untuk menangani ketidakseimbangan kelas pada dataset yang digunakan. Terdapat metode lain yaitu ADASYN yang merupakan pemutakhiran dari metode SMOTE.

Terdapat penelitian-penelitian terdahulu yang memiliki permasalahan imbalanced class dan diselesaikan menggunakan mekanisme oversampling seperti penelitian yang dilakukan oleh [4] yang mengembangkan sebuah metode prediksi yang digunakan untuk menyelesaikan masalah pada "lysine succinylation sites" dengan menggunakan 6 fitur sekuensial bernama Inspector. Metode tersebut terdiri dari Edited Nearest-Neighbor (ENN) sebagai metode undersampling dan Adaptive Synthetic Sampling Approach (ADASYN) sebagai metode oversampling pada saat proses penanganan imbalanced class pada data training. Kemudian diklasifikasikan menggunakan metode Random Forest dan menghasilkan akurasi prediksi sebesar 90\% dan AUC pada analisis ROC sebesar 0.96. Penelitian lain dilakukan oleh [5] yang menggunakan metode oversampling SMOTE dalam extreme learning machine untuk menangani imbalanced class. Dikatakan bahwa SMOTE meningkatkan signifikansi dari sampel kelas minoritas dengan membuat sampel sintetis dalam konteks penentuan klasifikasi yang kemudian membentuk sebuah model klasifikasi untuk imbalanced class data yang disebut SMOTE-CSELM. Penelitian yang lain dilakukan oleh [6] yang menggunakan ADASYN untuk menangani imbalanced class pada churn prediction dataset menggunakan metode Backpropagation. Penelitian tersebut menghasilkan akurasi sebesar $96.31 \%$.

Dalam kaitannya dengan optimalisasi proses pengolahan data, fungsi dari proses seleksi fitur menghasilkan dataset yang lebih ramping karena pengurangan jumlah atribut yang diperoleh dari pengukuran atribut-atribut yang memiliki pengaruh signifikan terhadap kelas. Terdapat metode-metode umum yang digunakan untuk mengetahui atribut mana yang memberikan pengaruh terhadap kelas dari dataset yang digunakan. Pendekatan berupa filter-based seperti pearson correlation dan chi-squared, wrapper-based seperti Recursive Feature Elimination (RFE), dan metode embedded seperti Lasso dapat digunakan sebagai metode seleksi fitur [7]. Seleksi fitur dapat meningkatkan kinerja dari metode data mining yang digunakan karena hanya memproses fitur-fitur terbaik saja dari data yang ada. Penggunaan RFECV sebagai metode seleksi fitur telah digunakan oleh penelitian-penelitian terdahulu. Seperti pada penelitian yang dilakukan oleh [8] dalam penyelesaian masalah deteksi gangguan pada keamanan jaringan dengan menggunakan klasifikasi Bernoulli Naïve Bayes dan Recursive feature Elimination with CrossValidation (RFECV). RFECV yang berfungsi sebagai mekanisme seleksi fitur dapat menentukan fitur-fitur yang penting dari dataset yang ada dan kemudian diklasifikasikan. Hasil dari penelitian tersebut adalah 
nilai AUC ROC sebesar 0.93. Penelitian lain dilakukan oleh [9] yang menggunakan RFECV untuk menghilangkan fitur yang tidak penting yang justru memberikan bias terhadap hasil klasifikasi pada permasalahan pengelompokan nanomaterial yang diklasifikasikan menggunakan Random Forest. Penelitian tersebut menghasilkan akurasi sebesar $82 \%$.

Dari permasalahan yang disampaikan sebelumnya dan dari penelitian-penelitian terkait yang telah dilakukan sebelumnya, penelitian ini berfokus pada proses penanganan imbalanced class yang terjadi pada dataset dan seleksi fitur untuk mempercepat proses pengolahan data dan meningkatkan performa dari metode klasifikasi. Selain itu, dari penelitian terdahulu yang telah disampaikan sebelumnya belum terdapat penelitian yang menggunakan kombinasi antara ADASYN dan RFECV untuk menangani dataset karyawan.

\section{Metode Penelitian}

Pada bagian ini akan dijelaskan alur dari penelitian ini. Dimulai dari pengambilan data, tahapan pre-processing untuk menghasilkan dataset yang siap untuk di proses menggunakan metode klasifikasi yang ditentukan. Tahapan pre-processing juga meliputi, missing values imputation, feature selection, dan imbalanced data handling yang merupakan poin utama dari penelitian ini. Untuk menguji perbandingan apakah proses feature selection dan imbalanced data handling dapat memberikan perbaikan pada akurasi yang dihasilkan oleh metode-metode klasifikasi yang ditentukan. Metode klasifikasi yang digunakan untuk menguji dataset yang digunakan adalah Random Forest, Decision tree, CART, Naïve Bayes, Logistic Regression, K-NN, Support Vector Machine, Bagging, dan Stacking di mana dua metode terakhir merupakan ensemble method yang dinilai memiliki performa yang lebih kuat dibandingkan dengan modelmodel klasifikasi tunggal. Gambar dari alur penelitian ini dapat dilihat pada Gambar 1.

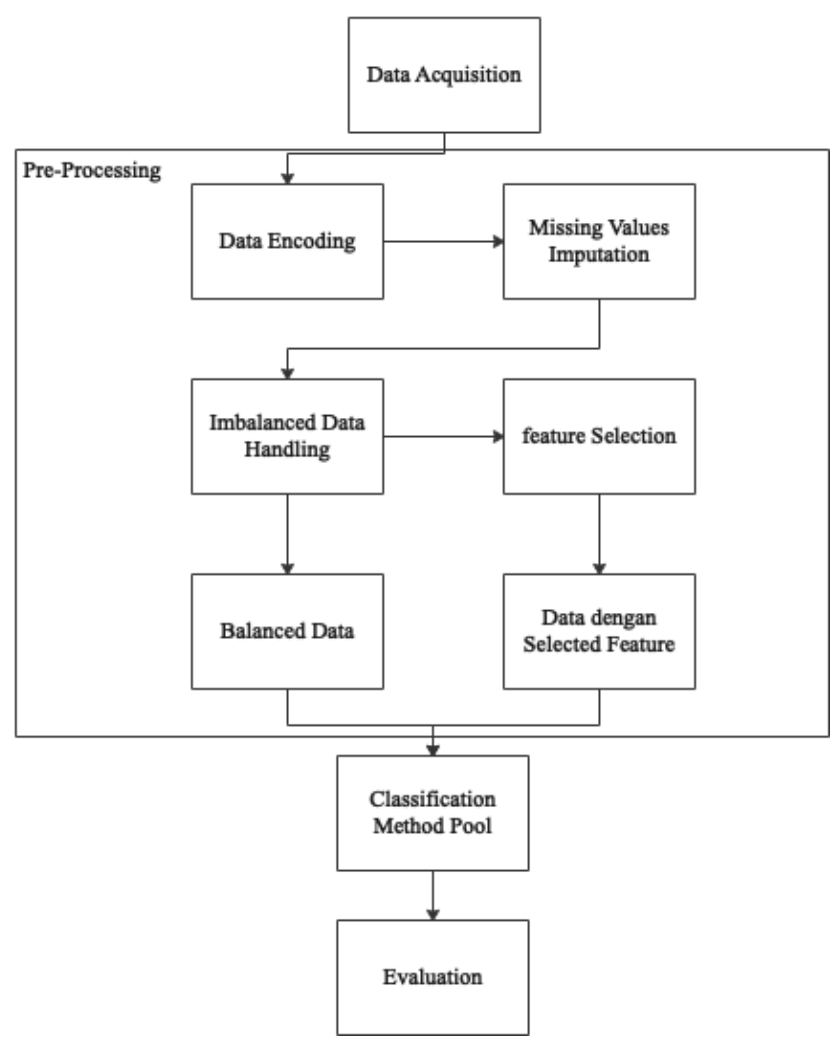

Gambar 1. Diagram penelitian.

\subsection{Data Acquisition}

Data yang digunakan pada penelitian ini adalah dataset yang diambil dari web kaggle.com dan juga dijadikan dataset untuk kompetisi data science. Data disajikan dalam bentuk CSV file yang akan digunakan dari setiap proses yang dilakukan pada penelitian ini. Data tersebut berisi 220005 data dari pegawai dengan semua data-data terkait demografis pegawai dan juga rekam jejak dari pekerjaan pegawai tersebut seperti lama bekerja, usia, pencapaian atau achievement yang sudah pernah didapatkan, dan lainlain. Jumlah distribusi untuk setiap kelas pada dataset ini adalah 19337 untuk kelas 0 (bukan karyawan 
dengan best performance) dan 2668 untuk kelas 1 (karyawan best performance). Jika dilihat secara langsung, proporsi jumlah data pada kedua kelas sangat tidak seimbang. Hal tersebut dapat menyebabkan bias pada hasil klasifikasi yang dilakukan jika kondisi tersebut tidak ditangani terlebih dahulu. Bentuk visual dari distribusi kelas pada dataset ini dapat dilihat pada Gambar 2 dan deskripsi dataset yang digunakan dapat dilihat pada Tabel 1 dan sampel dataset pada Tabel 2.

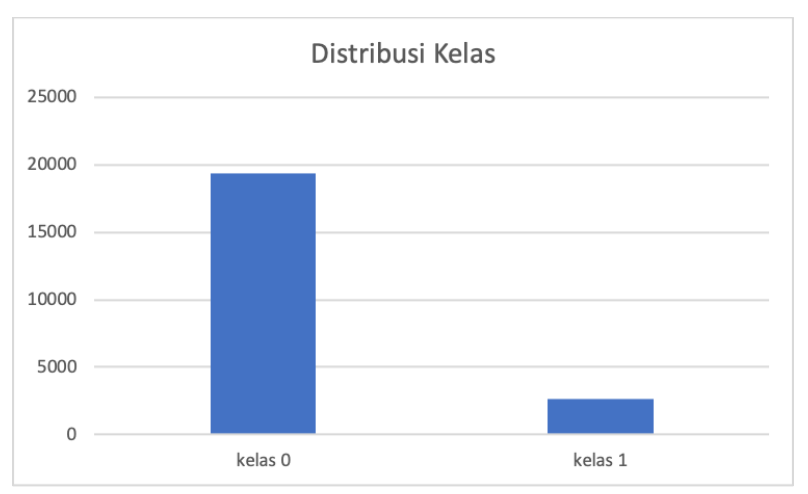

Gambar 2. Distribusi kelas.

Dari Gambar 2 dapat dilihat bahwa secara jumlah data pada setiap kelas sangat jauh berbeda. Perbedaan proporsi tersebut akan sangat mempengaruhi hasil proses data mining yang akan dilakukan selanjutnya. Karena hasil pada proses klasifikasi akan condong atau bias ke arah data-data yang ada pada kelas mayoritas. Oleh karena itu, data ini tidak dapat langsung di proses ke tahap data mining akan tetapi akan menjalani tahap pre-processing untuk memastikan semua kondisi yang tidak ideal di dalam dataset sudah terselesaikan.

Tabel 1. Deskripsi atribut dataset.

\begin{tabular}{|c|c|c|c|}
\hline No & Attribute & Tipe Data & Deskripsi \\
\hline 1 & Job_level & Nominal & $\begin{array}{l}\text { Level pekerjaan / jabatan dari karyawan tersebut saat ini } \\
\text { ditunjukkan oleh kode JG03-JG06 }\end{array}$ \\
\hline 2 & job_duration_in_current_job_level & Float & $\begin{array}{l}\text { Lama bekerja karyawan tersebut pada level pekerjaan / jabatan } \\
\text { saat ini. }\end{array}$ \\
\hline 3 & person_level & Nominal & $\begin{array}{l}\text { Level person dari karyawan tersebut ditunjukkan oleh kode } \\
\text { PG01-PG08 }\end{array}$ \\
\hline 4 & job_duration_in_current_person_level & Float & Lama bekerja pada level person saat ini. \\
\hline 5 & job_duration_in_current_branch & Float & Lama pekerjaan di kantor cabang saat ini \\
\hline 6 & Employee_type & Nominal & Jenis ikatan kerja ditunjukkan dengan RM_Type_A-RM-Type_A. \\
\hline 7 & Employee_status & Nominal & Status karyawan (kontrak / tetap) \\
\hline 8 & Gender & Nominal & Jenis Kelamin \\
\hline 9 & Age & Numerik & Umur ditunjukkan dengan Tahun lahir \\
\hline 10 & marital_status_maried(Y/N) & Nominal & Status Pernikahan \\
\hline 11 & number_of_dependences & Numerik & Jumlah tanggungan \\
\hline 12 & number_of_dependences (male) & Numerik & Jumlah tanggungan laki-laki \\
\hline 13 & number_of_dependences (female) & Numerik & Jumlah tanggungan Perempuan \\
\hline 14 & Education_level & Nominal & Level Pendidikan \\
\hline 15 & GPA & Float & Nilai Indeks Akademik \\
\hline 16 & Year_graduated & Numerik & Tahun Lulus \\
\hline 17 & job_duration_as_permanent_worker & Numerik & Lama bekerja sebagai pegawai \\
\hline 19 & job_duration_from_training & Numerik & Lama bekerja sejak pelatihan \\
\hline 20 & branch_rotation & Numerik & Jumlah rotasi bekerja di cabang berbeda \\
\hline 21 & job_rotation & Numerik & Jumlah rotasi pekerjaan \\
\hline 22 & assign_of_otherposition & Numerik & Jumlah penugasan pada posisi berbeda \\
\hline 23 & Annual leave & Numerik & Banyaknya cuti tahunan \\
\hline 24 & Sick_leaves & Numerik & Banyaknya izin sakit \\
\hline 25 & Avg_achievement_\% & Float & Rerata persentase pencapaian kinerja \\
\hline 26 & Last_achievement_\% & Float & Persentase capaian terakhir \\
\hline 27 & Achievement_above_100\%_during3quartal & Numerik & Jumlah pencapaian kinerja pada quartal ketiga yang di atas $100 \%$ \\
\hline 28 & achievement_target_1 & Nominal & Range ketercapaian target kesatu (achiev $>50 \%, \ldots$ ) \\
\hline 29 & achievement_target_2 & Nominal & Range ketercapaian target kedua (achiev_> $>50 \%, \ldots$ ) \\
\hline 30 & achievement_target_3 & Nominal & Ketercapaian capaian target ketiga (tercapai / tidak tercapai) \\
\hline 31 & Best Performance & Binary & $\begin{array}{l}\text { Kelas dari dataset, menunjukkan ketercapaian seorang karyawan } \\
\text { pada best performance. }(0 \text { dan } 1)\end{array}$ \\
\hline
\end{tabular}


Tabel 2. Sampel data.

\begin{tabular}{|c|c|c|c|c|c|c|c|}
\hline No & Job_level & $\begin{array}{l}\text { Job_duration_in } \\
\text { current_job_level }\end{array}$ & Person_level & Employee_type & Gender & $\ldots$ & Best_performance \\
\hline 1 & JG04 & 1.17 & PG03 & RM_type_A & Male & $\ldots$ & 0 \\
\hline 2 & JG04 & 1.83 & PG03 & RM_type_A & Male & $\ldots$ & 1 \\
\hline 3 & JG03 & 0.75 & PG01 & RM_type_B & Male & $\ldots$ & 0 \\
\hline 4 & JG03 & 0 & PG01 & RM_type_B & Male & $\ldots$ & 0 \\
\hline 5 & JG04 & 1.17 & PG03 & RM_type_A & Male & $\ldots$ & 0 \\
\hline 6 & JG04 & 0.75 & PG03 & RM_type_B & Male & $\ldots$ & 0 \\
\hline 7 & JG04 & 1.83 & PG03 & RM_type_B & Female & $\ldots$ & 1 \\
\hline 8 & JG03 & 0.75 & PG01 & RM_type_B & Male & $\ldots$ & 0 \\
\hline 9 & JG04 & 1.83 & PG03 & RM_type_B & Male & $\ldots$ & 0 \\
\hline 10 & JG04 & 1.17 & PG03 & RM_type_A & Male & $\ldots$ & 0 \\
\hline
\end{tabular}

\subsection{Pre-Processing}

Pada tahap Pre-Processing ini terdapat beberapa langkah yang dilakukan untuk mempersiapkan data mentah menjadi data yang siap digunakan untuk proses data mining selanjutnya. Langkah-langkah tersebut meliputi: transformasi data/data encoding; pengisian missing values; imbalanced data handling; seleksi fitur.

\subsubsection{Transformasi Data/Data Encoding}

Pada tahap ini, data-data yang memiliki bentuk data nominal akan di transformasi atau di-encode menjadi bentuk numerik. Bentuk transformasi data menggunakan mekanisme sederhana yaitu mengubah semua data nominal dengan kode numerik 0-n, di mana $\mathrm{n}$ adalah varian terakhir dari data nominal pada atribut tersebut. Contoh hasil transformasi data dapat dilihat pada Tabel 3.

Tabel 3. Hasil transformasi data.

\begin{tabular}{|c|c|c|c|c|c|c|c|}
\hline No & Job_level & $\begin{array}{l}\text { Job_duration_in } \\
\text { current_job_level }\end{array}$ & Person_level & Employee_type & Gender & ... & Best_performance \\
\hline 1 & 4 & 1.17 & 3 & 0 & 1 & $\ldots$ & 0 \\
\hline 2 & 4 & 1.83 & 3 & 0 & 1 & $\ldots$ & 1 \\
\hline 3 & 3 & 0.75 & 1 & 1 & 1 & $\ldots$ & 0 \\
\hline 4 & 3 & 0 & 1 & 1 & 1 & $\ldots$ & 0 \\
\hline 5 & 4 & 1.17 & 3 & 0 & 1 & $\ldots$ & 0 \\
\hline 6 & 4 & 0.75 & 3 & 1 & 1 & $\ldots$ & 0 \\
\hline 7 & 4 & 1.83 & 3 & 1 & 0 & $\ldots$ & 1 \\
\hline 8 & 3 & 0.75 & 1 & 1 & 1 & $\ldots$ & 0 \\
\hline 9 & 4 & 1.83 & 3 & 1 & 1 & $\ldots$ & 0 \\
\hline 10 & 4 & 1.17 & 3 & 0 & 1 & $\ldots$ & 0 \\
\hline
\end{tabular}

\subsubsection{Penanganan Missing Values}

Tahapan ini memiliki peran cukup penting dari keseluruhan proses penelitian ini, pengisian missing values dimaksudkan untuk menjaga jumlah data yang bisa digunakan untuk proses data mining selanjutnya. Dataset yang digunakan memiliki jumlah missing values yang tidak sedikit. Rangkuman jumlah missing values pada setiap atribut yang terdapat pada data ini dapat dilihat pada Gambar 3 . 


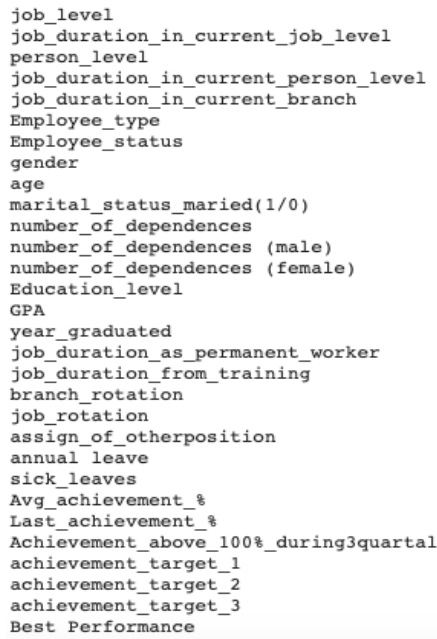

Gambar 3. Jumlah missing values per atribut.

Missing values pada dataset ini akan diselesaikan menggunakan pendekatan imputation, yaitu proses mengisi missing values dengan nilai-nilai hasil estimasi menggunakan metode tertentu. Selain imputation pendekatan penanganan missing values dapat berupa penghapusan baris data yang memiliki missing values, akan tetapi pendekatan tersebut akan mengakibatkan jumlah dataset semakin berkurang drastis jika jumlah missing values yang terdapat pada dataset berjumlah banyak.

Metode yang digunakan untuk melakukan missing values imputation pada dataset ini adalah Missforest [10][11]. Missforest merupakan teknik missing values imputation berbasis pada metode Random Forest di mana metode ini menggunakan model Random Forest pada data yang tersedia pada dataset untuk kemudian melakukan estimasi pada missing values pada dataset tersebut [11]. MissForest dapat digunakan untuk pengisian missing values pada dataset dengan tipe data yang heterogeny (mixed data-type) [10]. Dataset hasil missing values imputation menggunakan metode Missforest dapat dilihat pada Tabel 4.

Tabel 4. Sampel atribut sebelum \& setelah missing values imputation.

\begin{tabular}{ccc}
\hline No & $\begin{array}{c}\text { Atribut Last_achievement_\% } \\
\text { (sebelum missing values imputation) }\end{array}$ & $\begin{array}{c}\text { Atribut Last_achievement_\% } \\
\text { (setelah missing values imputation) }\end{array}$ \\
\hline 1 & $?$ & 33.0385 \\
\hline 2 & 46.8 & 46.8 \\
\hline 3 & $?$ & 32.1895 \\
\hline 4 & $?$ & 31.4021 \\
\hline 5 & $?$ & 38.1723 \\
\hline 6 & $?$ & 22.6998 \\
\hline 7 & $?$ & 33.0385 \\
\hline
\end{tabular}

\subsubsection{Imbalanced Data Handling}

Imbalanced data merupakan sebuah kondisi di mana distribusi dari kelas yang terdapat pada dataset tidak seimbang jumlahnya. Selisih jumlah data yang terdapat pada masing-masing kelas akan dapat mempengaruhi performa dari metode klasifikasi jika tidak ditangani karena akan menimbulkan bias terhadap kelas mayoritas[12]. Hal yang membuat data imbalanced tidak ideal untuk langsung diproses adalah permasalahan proporsi data yang dapat mengurangi kinerja dari algoritma klasifikasi standar. Terdapat beberapa cara menangani kondisi imbalanced pada sebuah dataset dan dapat dikategorikan menjadi dua jenis pendekatan, yaitu pendekatan level data, pendekatan level algoritme, dan hybrid antara keduanya [2]. Ilustrasi dari metode untuk masing-masing jenis pendekatan dalam menangani imbalanced dataset dapat dilihat pada Gambar 4. 


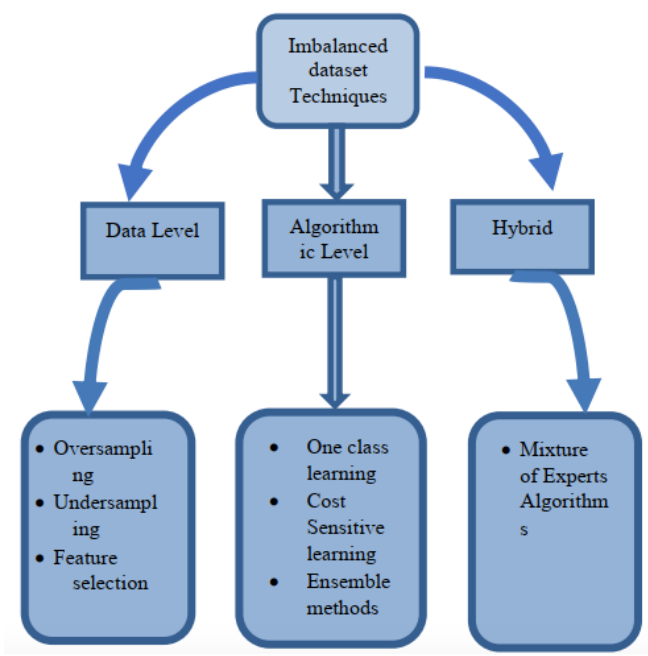

Gambar 4. Penanganan imbalanced dataset [2].

Pendekatan level data untuk menyelesaikan imbalanced dataset dapat disebut sebagai metode eksternal karena dilakukan di luar proses data mining secara umum (masih ada di tahap pra-pemrosesan). Pendekatan ini mencoba untuk menyeimbangkan proporsi data dengan cara mengurangi jumlah data pada kelas mayoritas, atau meningkatkan jumlah data pada kelas minoritas dengan metode sintetisasi yang juga disebut Undersampling dan Oversampling. Secara umum pendekatan pada level data memiliki 3 metode yaitu oversampling, undersampling, dan feature selection.

Pada pendekatan level algoritme atau biasa disebut pendekatan internal dikarenakan terjadi pada pemrosesan data dengan mengimplementasikan metode baru atau meningkatkan kapabilitas metode klasifikasi yang ada untuk dapat menangani permasalahan bias yang disebabkan oleh imbalanced data. Pendekatan level algoritme dikategorikan menjadi ensemble-based method, threshold methods, one class learning, cost sensitive learning, dan active learning methods. Pendekatan ketiga adalah model hybrid yang merupakan kombinasi antara kedua pendekatan yang telah dijelaskan sebelumnya. Sebagaimana disampaikan pada penelitian [2] bahwa penanganan imbalanced dataset terbukti efektif menggunakan SMOTE yang mana adalah metode Oversampling. Sehingga pada penelitian ini metode Oversampling akan menjadi solusi untuk menangani imbalanced data. Metode Oversampling yang digunakan pada penelitian ini adalah Adaptive Synthetic (ADASYN). ADASYN merupakan metode resampling yang termasuk ke dalam kategori oversampling, dan ADASYN merupakan sebuah pengembangan dari metode SMOTE. Dengan menggunakan metode yang lebih mutakhir daripada SMOTE diharapkan dapat meningkatkan performa dari metode klasifikasi yang digunakan nantinya [13].

\subsubsection{Feature Selection}

Seperti yang dapat dilihat pada bagian deskripsi dataset bahwa jumlah atribut yang terdapat pada dataset yang digunakan berjumlah 30 atribut dan 1 atribut kelas. Namun apakah semua atribut yang terdapat pada dataset tersebut memberikan kontribusi terhadap kelas atribut atau justru mengganggu proses klasifikasi dan dianggap sebagai noise. Untuk dapat mengetahui hal tersebut, maka digunakanlah sebuah metode feature selection atau feature ranking untuk dapat mengetahui berapa jumlah optimal dan mana saja atribut yang memberikan kontribusi terhadap kelas atribut dan dapat meningkatkan performa klasifikasi. Pada penelitian ini metode feature selection yang digunakan adalah Recursive Feature Elimination and Cross-Validation (RFECV) [8][9]. Penggunaan feature selection dapat meningkatkan akurasi dari klasifikasi karena asumsinya hanya atribut-atribut yang dianggap penting saja yang akan digunakan, dan hal tersebut otomatis akan memangkas waktu pemrosesan karena data yang diolah menjadi semakin sedikit. Tetapi karena data yang diolah menjadi sedikit, akan dikhawatirkan juga justru melemahkan kinerja klasifikasi karena dimungkinkan ada data-data yang sebenarnya penting justru tereliminasi oleh proses feature selection tersebut. Oleh sebab itu, pada penelitian ini. Kedua hasil akan dibandingkan untuk menunjukkan apakah penggunaan feature selection dapat meningkatkan akurasi dari klasifikasi atau tidak. Metode RFECV di implementasikan menggunakan library yang terdapat pada scikit.learn Python dengan parameter cross-validation $=10$. 


\subsubsection{Klasifikasi}

Pada tahap ini, dataset yang telah melalui tahap pre-processing akan melalui proses klasifikasi untuk kemudian diuji akurasinya pada tahap evaluasi. Karena data yang digunakan adalah dataset klasifikasi karyawan yang artinya setiap kelas memiliki pola tersendiri. Metode untuk melakukan klasifikasi sudah sangat banyak dan sudah berkembang menjadi model-model dengan pendekatan yang berbeda-beda pula. Metode-metode dasar dari klasifikasi yang sudah sering digunakan adalah Decision Tree yang pertama kali muncul pada penelitian [14]. Untuk model Decision Tree saja saat ini sudah ada algoritma hasil pengembangannya yaitu Random Forest yang dikembangkan pertama kali oleh Breiman pada penelitian [15]. Selain pendekatan model pohon keputusan seperti dua metode yang telah disebutkan, masih ada model lain yang menggunakan pendekatan mathematical modelling seperti support vector machine [16][17]. Algoritma klasifikasi lain adalah Nä̈ve Bayess yang menggunakan konsep probabilitas dalam proses klasifikasinya[18]. Dari sekian banyak metode klasifikasi baik bentuk dasar maupun pengembangan pasti memiliki keunggulan dan kelemahan masing-masing. Pada penelitian ini, proses perbandingan antara metode-metode klasifikasi akan dilakukan untuk mencari tahu manakah metode yang terbaik yang dapat digunakan pada dataset ini. Karena setiap karakteristik data mungkin membutuhkan pendekatan yang berbeda pada pengolahannya.

Dalam perkembangannya, metode klasifikasi sudah sampai di mana terdapat teknik yang menggabungkan lebih dari satu metode klasifikasi untuk membentuk sebuah algoritme klasifikasi yang lebih kuat. Teknik tersebut adalah ensemble method, ensemble method mengombinasikan lebih dari satu metode klasifikasi dasar dengan tujuan menghasilkan sebuah model yang lebih akurat dibanding dengan metode klasifikasi secara individu [19]. Terdapat beberapa model ensemble method yang popular digunakan pada penelitian-penelitian terkait klasifikasi di antaranya, Stacking, Bagging (Bootstrap Aggregation), dan Boosting. Stacking merupakan sebuah ensemble method yang menggunakan lebih dari satu metode klasifikasi dasar. Salah satu dari metode tersebut akan digunakan untuk dilatih menggunakan dataset yang ada, dan kemudian membentuk dataset baru. Metode yang digunakan pada tahap awal disebut sebagai meta learner. Dataset baru yang terbentuk kemudian akan menjadi input untuk metode klasifikasi selanjutnya yang kemudian mengeluarkan hasil akhir klasifikasi. Model kedua adalah Bagging, metode ini membentuk beberapa model yang dibentuk dari sebuah algoritma klasifikasi yang sama dengan menggunakan sub-sampel yang diambil dari dataset secara acak menggunakan metode bootstrap sampling. [20]. Model ketiga adalah Boosting, metode ini secara umum adalah sebuah metode yang dapat mengonversikan model yang lemah menjadi model yang kuat. Boosting secara incremental membentuk sebuah ensemble dengan melatih setiap model menggunakan data yang sama dengan penyesuaian bobot dari data berdasarkan hasil prediksi terakhir [1]. Penelitian ini menggunakan beberapa algoritma klasifikasi yang akan dibandingkan satu sama lain untuk mencari tahu mana metode yang paling baik untuk dataset yang digunakan. Metode-metode tersebut adalah, Logistic Regression[18], Decision Tree [21], Nä̈ve Bayes [22], k-NN [23], CART, Support Vector Machine (SVM), Random Forest [15], Stacking [24][25], Bagging $[20]$.

\subsubsection{Evaluasi}

Pada tahap evaluasi, penelitian ini menggunakan metrik pengukuran $k$-fold cross-validation untuk setiap metode klasifikasi yang digunakan. Cara kerja metode ini adalah membagi dataset menjadi subset dengan proporsi tertentu secara acak sebanyak nilai $k$ yang dikehendaki. Lalu untuk setiap subset akan melalui proses training-testing di mana salah satu dari subset tersebut akan digunakan sebagai data test. Proses tersebut akan diulangi sampai semua subset telah berperan menjadi data test. Tidak terdapat jumlah baku terkait nilai $k$ pada metode pengukuran akurasi ini. Tetapi beberapa penelitian terdahulu menggunakan $k=5$ atau $k=10$, di mana saat nilai $k$ semakin besar maka perbedaan kuantitas antara data latih dan subset yang telah di sampling ulang menjadi lebih kecil. Ketika perbedaan tersebut menjadi semakin kecil, nilai bias pada metode ini juga menjadi semakin kecil [7]. Pada penelitian ini nilai koefisien $k$ yang digunakan adalah $k=10$.

\section{Hasil dan Pembahasan 3.1. Imbalanced Data}

Pada tahap penanganan imbalanced data, data ditangani menggunakan metode ADASYN. Jumlah dari hasil sintetisasi metode ADASYN memang tidak sama persis, tetapi relatif seimbang. Hasil dari penanganan imbalanced data dapat dilihat pada Gambar 5. 


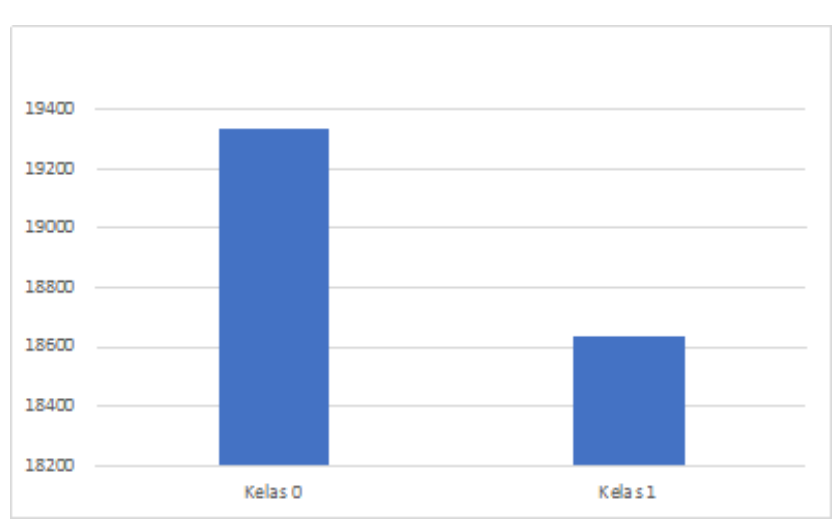

Gambar 5. Sintetisasi menggunakan ADASYN.

Pada Gambar 5 dapat dilihat bahwa secara angka jumlah data pada masing-masing kelas tidak sama persis, tetapi model penyelesaian imbalanced data menggunakan ADASYN memang tidak pernah menghasilkan sintetisasi data yang sama untuk masing-masing kelasnya. Hal ini dimungkinkan oleh jumlah data pada kelas minoritas yang terlalu jauh selisihnya dengan kelas mayoritas. Setelah tahap penanganan imbalanced data selesai, kemudian data akan menjalani dua jalur berbeda, yaitu tahap seleksi fitur yang akan dibahas pada bagian selanjutnya dan tanpa fitur seleksi yang kemudian nantinya akan dibandingkan seberapa berbeda kedua model tersebut.

\subsection{Seleksi Fitur}

Data yang telah melalui tahap preprocessing yaitu tahap pengisian missing values dan penanganan imbalanced class selanjutnya akan melalui tahapan seleksi fitur. Seleksi fitur adalah sebuah tahapan di mana memilih atau melakukan filtrasi terhadap atribut data yang banyak kemudian menjadi lebih sedikit dengan tujuan menghilangkan atribut/fitur yang tidak memiliki kontribusi atau pengaruh terhadap kelas data. Dengan menggunakan metode RFECV, fitur data yang berjumlah 29 atribut kemudian akan dilihat pada jumlah fitur dan fitur yang mana saja yang paling optimal untuk digunakan untuk tahap klasifikasi, hasil dari metode RFECV dapat dilihat pada Gambar 6.

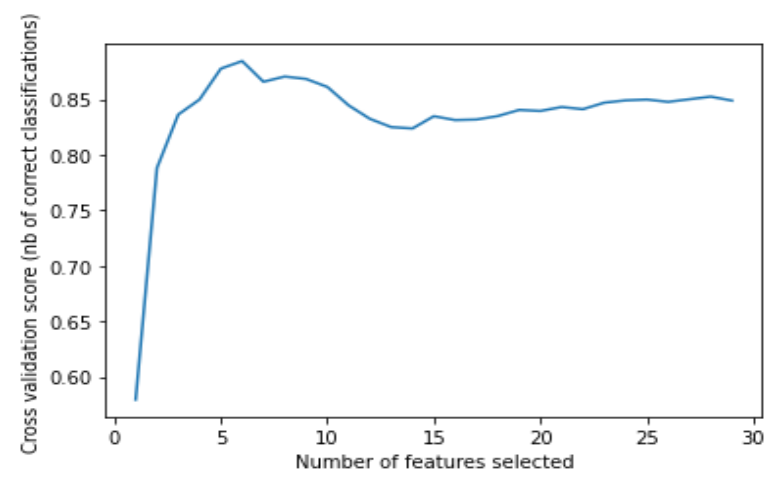

Gambar 6. Seleksi fitur menggunakan RFECV.

Dari Gambar 6 dapat dilihat bahwa jumlah optimal yang didapat untuk dataset ini adalah 6 fitur dengan hasil cross-validation mencapai lebih dari $0.85(85 \%)$. Dengan jumlah fitur yang telah diketahui maka dari itu dapat diambil kesimpulan bahwa tidak semua fitur pada dataset ini optimal untuk digunakan pada proses klasifikasi, ada lebih banyak data yang mengandung noise dibanding data yang menunjang hasil klasifikasi. Hal tersebut dapat dilihat dari hasil grafik yang menurun cukup drastis pada jumlah fitur di atas 6. setelah itu, identifikasi mana saja fitur yang menjadi bagian dari ke-enam fitur yang optimal tersebut akan dilakukan. Menggunakan fungsi yang terdapat pada library RVECV untuk menampilkan rangking atau peringkat dapat dilihat mana saja fitur yang dianggap optimal. Hasil dari keluaran fungsi tersebut dapat dilihat pada Gambar 7. 


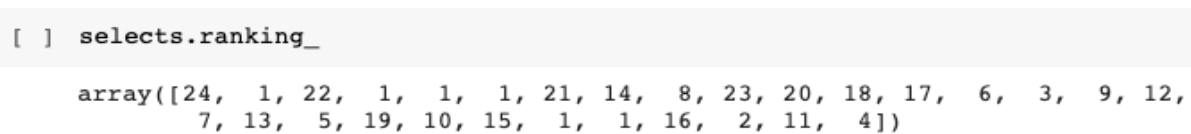

Gambar 7. Peringkat fitur.

Pada Gambar 7 dapat dilihat peringkat dari setiap fitur atau atribut yang ada pada dataset. Urutan yang tertera pada array tersebut adalah urutan dari atribut yang ada pada dataset. Jika dijabarkan dan dituliskan dalam bentuk nama atribut, atribut atau fitur yang berada pada peringkat 1 adalah antara lain:

- "job_duration_in_current_job_level"

- “job_duration_in_current_person_level”

- "job_duration_in_current_branch"

- "Employee type"

- "Avg achievement \%"

- "Last_achievement_\%"

Menggunakan hasil seleksi fitur tersebut, maka dataset akan di reduksi jumlah atributnya berdasarkan hasil tersebut. Pada tahapan selanjutnya, dua model dataset (dengan fitur seleksi dan tanpa fitur seleksi) akan diklasifikasi menggunakan metode-metode yang telah ditentukan sebelumnya yang kemudian dievaluasi menggunakan metrik pengukuran k-fold cross validation.

\subsubsection{Klasifikasi dan Evaluasi}

Untuk mendapatkan hasil yang komprehensif terkait klasifikasi dari dua buah model dataset yang telah disiapkan dan kemudian mengetahui mana model klasifikasi yang tepat dan cocok untuk digunakan untuk dataset ini, beberapa metode klasifikasi yang berbeda digunakan untuk diketahui hasil evaluasinya menggunakan $k$-fold cross validation. Hasil akurasi dari masing-masing metode klasifikasi untuk masingmasing dataset berbeda dapat dilihat pada Tabel 5.

Tabel 5. Tabel perbandingan akurasi klasifikasi.

\begin{tabular}{llcc}
\hline \multirow{2}{*}{ No } & \multirow{2}{*}{ Metode Klasifikasi } & \multicolumn{2}{c}{ Akurasi } \\
\cline { 3 - 4 } & & Tanpa Fitur Seleksi & Hasil RFECV \\
\hline 1 & Random Forest & $78 \%$ & $88 \%$ \\
\hline 2 & Logistic Regression & $63.4 \%$ & $87.9 \%$ \\
\hline 3 & Decision tree & $78 \%$ & $85 \%$ \\
\hline 4 & Naïve Bayes & $55.5 \%$ & $85.2 \%$ \\
\hline 5 & k-NN & $81.1 \%$ & $86.6 \%$ \\
\hline 6 & CART & $\mathbf{8 5 . 1 \%}$ & $79.1 \%$ \\
\hline 7 & SVM & $55.5 \%$ & $87.9 \%$ \\
\hline 8 & Stacking & $82 \%$ & $87.9 \%$ \\
\hline 9 & Bagging k-NN & $68 \%$ & $\mathbf{8 8 \%}$ \\
\hline
\end{tabular}

Dari tabel 6 dapat dilihat perbandingan dari masing-masing metode klasifikasi yang digunakan terhadap dua buah model dataset yaitu dataset yang tidak melalui proses seleksi fitur, dan dataset yang melalui tahap seleksi fitur. Pada hasil klasifikasi tanpa seleksi fitur, hasil terbaik dihasilkan oleh metode CART dengan $85.1 \%$ akurasi. Sedangkan pada dataset dengan seleksi fitur, hasil akurasi klasifikasi terbaik dihasilkan oleh metode Bagging k-NN yang merupakan salah satu dari ensemble technique dengan akurasi sebesar $88 \%$. Secara umum hasil klasifikasi dari metode-metode yang digunakan pada dataset dengan proses seleksi fitur lebih baik dibandingkan pada dataset asli tanpa proses seleksi fitur.

\section{Kesimpulan}

Dari permasalahan yang telah dikemukakan pada bagian pendahuluan bahwa pengolahan data yang efektif dan efisien diperlukan untuk mempercepat proses pengambilan keputusan, terutama untuk menentukan pola untuk mengetahui pegawai yang berada pada best performance atau tidak. Sebagai salah satu cara untuk mengefisienkan proses klasifikasi, seleksi fitur dapat memenuhi kebutuhan tersebut karena hasil dati seleksi fitur adalah sebuah dataset dengan jumlah atribut yang lebih sedikit dari sebelumnya. Setelah dilakukan evaluasi dari hasil klasifikasi pada dataset yang menggunakan seleksi fitur, didapatkan hasil klasifikasi yang lebih baik dibandingkan dengan hasil klasifikasi pada dataset tanpa seleksi fitur. Hal tersebut dibuktikan dengan perbandingan antara hasil terbaik dari akurasi klasifikasi dataset tanpa seleksi fitur yang dihasilkan oleh CART sebesar $85.1 \%$ tidak lebih baik dari metode Bagging k-NN yang di 
aplikasikan pada dataset dengan seleksi fitur yang menghasilkan $88 \%$ akurasi. Sehingga dapat disimpulkan bahwa seleksi fitur dapat meningkatkan akurasi pada klasifikasi.

\section{Daftar Pustaka}

[1] H. Jiawei and M. Kamber, Data mining: concepts and techniques. 2001.

[2] V. S. Spelmen and R. Porkodi, "A Review on Handling Imbalanced Data," Proc. 2018 Int. Conf. Curr. Trends Towar. Converging Technol. ICCTCT 2018, pp. 1-11, 2018, doi: 10.1109/ICCTCT.2018.8551020.

[3] H. Kuswanto and A. Naufal, "Evaluation of performance of drought prediction in Indonesia based on TRMM and MERRA-2 using machine learning methods," MethodsX, vol. 6, no. March, pp. 1238-1251, 2019, doi: 10.1016/j.mex.2019.05.029.

[4] Y. Zhu, C. Jia, F. Li, and J. Song, "Inspector: a lysine succinylation predictor based on edited nearest-neighbor undersampling and adaptive synthetic oversampling," Anal. Biochem., vol. 593, no. January, p. 113592, 2020, doi: 10.1016/j.ab.2020.113592.

[5] B. S. Raghuwanshi and S. Shukla, "SMOTE based class-specific extreme learning machine for imbalanced learning," Knowledge-Based Syst., vol. 187, p. 104814, 2020, doi: 10.1016/j.knosys.2019.06.022.

[6] A. Aditsania, Adiwijaya, and A. L. Saonard, "Handling imbalanced data in churn prediction using ADASYN and backpropagation algorithm," Proceeding - 2017 3rd Int. Conf. Sci. Inf. Technol. Theory Appl. IT Educ. Ind. Soc. Big Data Era, ICSITech 2017, vol. 2018-January, pp. 533-536, 2017, doi: 10.1109/ICSITech.2017.8257170.

[7] M. Kuhn and K. Johnson, Applied Predictive Modeling with Applications in R, vol. 26. 2013.

[8] M. Artur, "Review the performance of the Bernoulli Naïve Bayes Classifier in Intrusion Detection Systems using Recursive Feature Elimination with Cross-validated selection of the best number of features," Procedia Comput. Sci., vol. 190, no. 2019, pp. 564-570, 2021, doi: 10.1016/j.procs.2021.06.066.

[9] A. Bahl et al., "Recursive feature elimination in random forest classification supports nanomaterial grouping," NanoImpact, vol. 15, no. June, p. 100179, 2019, doi: 10.1016/j.impact.2019.100179.

[10] D. J. Stekhoven and P. Bühlmann, "Missforest-Non-parametric missing value imputation for mixedtype data," Bioinformatics, vol. 28, no. 1, pp. 112-118, 2012, doi: 10.1093/bioinformatics/btr597.

[11] F. Tang and H. Ishwaran, "Random forest missing data algorithms," Stat. Anal. Data Min., vol. 10, no. 6, pp. 363-377, 2017, doi: 10.1002/sam.11348.

[12] T. E. Tallo and A. Musdholifah, "The Implementation of Genetic Algorithm in Smote (Synthetic Minority Oversampling Technique) for Handling Imbalanced Dataset Problem," in 2018 4th International Conference on Science and Technology (ICST), 2018, pp. 1-4.

[13] Y. Pristyanto, I. Pratama, and A. F. Nugraha, "Data level approach for imbalanced class handling on educational data mining multiclass classification," in 2018 International Conference on Information and Communications Technology, ICOIACT 2018, 2018, vol. 2018-Janua, doi: 10.1109/ICOIACT.2018.8350792.

[14] S. Gavankar and S. Sawarkar, "Decision Tree: Review of Techniques for Missing Values at Training, Testing and Compatibility," in 2015 3rd International Conference on Artificial Intelligence, Modelling and Simulation (AIMS), 2015, pp. 122-126, doi: 10.1109/AIMS.2015.29.

[15] L. Breiman, "Random Forests," Int. J. Adv. Comput. Sci. Appl., 2001.

[16] R. Berwick, "An Idiot's Guide to Support vector machines (SVMs): A New Generation of Learning Algorithms Key Ideas," pp. 1-28, 2003.

[17] L. Mohan, J. Pant, P. Suyal, and A. Kumar, "Support Vector Machine Accuracy Improvement with Classification," Proc. - 2020 12th Int. Conf. Comput. Intell. Commun. Networks, CICN 2020, pp. 477-481, 2020, doi: 10.1109/CICN49253.2020.9242572.

[18] M. R. Romadhon and F. Kurniawan, "A Comparison of Naive Bayes Methods, Logistic Regression and KNN for Predicting Healing of Covid-19 Patients in Indonesia," 3rd 2021 East Indones. Conf. Comput. Inf. Technol. EIConCIT 2021, pp. 41-44, 2021, doi: 10.1109/EIConCIT50028.2021.9431845.

[19] S. Ahmed, A. Mahbub, F. Rayhan, R. Jani, S. Shatabda, and D. M. Farid, "Hybrid Methods for Class Imbalance Learning Employing Bagging with Sampling Techniques,” 2nd Int. Conf. Comput. Syst. Inf. Technol. Sustain. Solut. CSITSS 2017, pp. 1-5, 2018, doi: 10.1109/CSITSS.2017.8447799.

[20] L. Breiman, "Bagging predictors," Mach. Learn., vol. 24, no. 2, pp. 123-140, 1996, doi: 10.1007/BF00058655.

[21] L. Rokach and O. Maimon, Data Mining With Decision Trees: Theory and Applications, 2nd ed. 
River Edge, NJ, USA: World Scientific Publishing Co., Inc., 2014.

[22] D. Soni, "Introduction to Naive Bayes Classification," 2018. [Online]. Available: https://towardsdatascience.com/introduction-to-naive-bayes-classification-4cffabb1ae54. [Accessed: 06-May-2019].

[23] C. Tang, P. Xu, Z. Luo, G. Zhao, and T. Zou, "Automatic facial expression analysis of students in teaching environments," Lect. Notes Comput. Sci. (including Subser. Lect. Notes Artif. Intell. Lect. Notes Bioinformatics), vol. 9428, pp. 439-447, 2015, doi: 10.1007/978-3-319-25417-3_52.

[24] K. Leartpantulak and Y. Kitjaidure, "Music genre classification of audio signals using particle swarm optimization and stacking ensemble," iEECON 2019 - 7th Int. Electr. Eng. Congr. Proc., pp. 1-4, 2019, doi: 10.1109/iEECON45304.2019.8938995.

[25] J. Ling and G. Li, "A two-level stacking model for detecting abnormal users in Wechat activities," Proc. - 2019 Int. Conf. Inf. Technol. Comput. Appl. ITCA 2019, pp. 229-232, 2019, doi: 10.1109/ITCA49981.2019.00057. 